\title{
A QUALITATIVE STUDY ON LEARNING ORGANIZATION AS AN ESSENTIAL ACTION LOWERING SKILL MISMATCH EFFECTS
}

\author{
Yustina Erti Pravitasmara DEWI ${ }^{1}$, Christantius DWIATMADJA ${ }^{2}$, Lieli SUHARTI ${ }^{3}$
}

\author{
Universitas Kristen Satya Wacana, Salatiga, Indonesia \\ E-mails: ${ }^{1}$ yustina.erti@staff.uksw.edu (corresponding author); ${ }^{2}$ christantius.dwiatmadja@staff.uksw.edu; \\ ${ }^{3}$ lieli.suharti@staff.uksw.edu
}

Received 29 October 2018; accepted 27 December 2018

\begin{abstract}
Skill mismatch phenomenon has been discussed in various scientific journals as it is proven to lower productivity and weaken competitiveness. Understanding the skill mismatch effect on competitiveness leads to a new way of thinking about how to manage skill mismatch for the organization sustainability. Previous researches recognize the concept of organizational management in order to be able to compete by creating a learning organization environment. Adhering to the learning organization principles, individuals within the organization should increase their capacity and thus minimizing the negative effects caused by the skill mismatch effects. This study chooses hotel business as an observation unit as the hotel is such a storefront of tourism in Indonesia. The research was done in a descriptive-qualitative manner and used five-stars hotel in Indonesia. The results supported the previous researches on learning organization and training prior to working The findings indicated that in the process of organizational learning in the hospitality business, it was originally started with the involvement of the company or institutionalizing. The originality of this research is presented in the use of the $4 \mathrm{i}$ framework in organizational learning to evaluate the skill mismatch.
\end{abstract}

Keywords: skill mismatch, learning organization, training, mentoring, working, hotel, tourism.

JEL Classification: D22, J24, O15.

\section{Introduction}

The discussion on previous researches about skill mismatch is more desirable at the macro level. Skill mismatch is an interesting research topic because it is assumed to be one of the factors slowing the economic growth in the United States (Guvenen et al. 2015, Abraham 2015). The incidents, consequences, and measurements of skill mismatch have been published in statistical reports of the ILO (2014) for cases in the European region. In the reports, the skill mismatch is defined as terminology that represents various types of imbalances between the skills possessed and the skills needed in the world of work. The researches on skill mismatch are then directed to find evidence of skill mismatch occurrences and their effects on productivity both at the corporate and the macro level, as what had been done previously by Allen and Vries (2004), Bender and Heywood
(2011), Chowdhury (2014), Dobbs and Madgavkar (2014), Mahy et al. (2015) and Pellizzari and Fichen (2013).

Skill mismatch has a negative impact at the individuals, organizations, and the macro environment level. At the individual level, a study by Santos (2012) examined the phenomenon of over education and the consequences on dissatisfaction at work that tended to produce high absences, health problems, and directly related to compensation. At the macro level, Modestino (2010) found that the skill mismatch would be the cause of structured unemployment in the future and this is precisely the case amid the high economic growth. The skill mismatch is also an interesting topic to study supported by various academic articles taking locations in various continents. Linking skill mismatch and salary was examined by Korpi and Tahlin (2009) by using the data from Sweden also by Park (2013) in South Korea. Discussions on skill mismatches in the Australian labor

Copyright $\odot 2019$ The Authors. Published by VGTU Press.

This is an Open Access article distributed under the terms of the Creative Commons Attribution License (http://creativecommons.org/licenses/by/4.0/), which permits unrestricted use, distribution, and reproduction in any medium, provided the original author and source are credited.. 
market were also presented in scientific articles by Chiswick and Miller (2010) and Messinis and Olekalns (2007). From Malaysia (Anuar et al. 2016) examined skill mismatch in small medium enterprises.

The European Center for the Development of Vocational Training by Cedefop (2012) published the results of their researches on the role of companies in overcoming skill mismatches. The publications noted that companies with certain characteristics such as low salary levels and poor working conditions - such as in the tourism industry, hotels, and restaurants - were thought to be easier to experience skill mismatch conditions. In Indonesia, as an archipelago nation that relies on tourism as one of the mainstays of foreign exchange, is the country with the most population in ASEAN but has fewer foreign tourists than its neighbors such as Singapore, Malaysia, and Thailand (WEC 2017). Research by Suherlan and Permana (2016) linked the issue of tourism in Indonesia with Human Resources problems. The article mentioned that HR issues in the tourism industry were related to the following matters such as the decline in the community's interest to enroll in tourism high schools, teaching and learning processes that mainly focused on hard skills and not yet referred to the quality of global tourism, the graduates who were not in accordance with the demand of the industry, and the quality culture which had not been institutionalized in the process of implementing education. Indonesia Hotel Watch by Poh et al. (2016) published by HVS Singapore said that the hotel growth rate continued to increase every year, as in the branded hotel rooms category in 2015-2016 increased by $10.2 \%$. In Indonesia, there has been an increase in the number of progressive hotels but not accompanied by an increase in the number of skilled workers (Kurniawan 2016, Santoso 2014).

Cedefop (2012) published that the working industry which was prone to experience skill mismatch was the hospitality business. In Indonesia, the availability of the human resources for this business shows that the demand is higher than the supply. Therefore, it can be concluded that this condition represents what was assumed by Cedefop (2012) previously. In the report, it is described in general how companies play a role in overcoming the skill mismatch. Thus, the mismatch skill issue is not enough to be seen in only from a macro perspective. The organization has a role to change the skill mismatch situation for their employees to have matching skills. One of the most important issues that need to be considered by organizational managers and policy makers is the lifelong learning which is also a priority in the European Union in organizing strategic cooperation between education and training.

In the previous study, Wang and Ellinger (2008) stated that learning is a process that is supported by the organization and practiced in multiple levels of learning. The research strengthens Senge (1990) opinion about learning organizations as places for people to continuously expand their capacity to get the desired results. Thus, it can be expected that learning organization will help to resolve skill mismatch situations. The research statement in this research are about to answer these two questions, namely: 1) how does the skill mismatch occur in the hotel industry? and 2) how can learning organizations play a role in the skill mismatch phenomenon? The originality of this research is to link the skill mismatch phenomenon with the organizational management literature, namely organizational learning.

To answer these two questions, this research analyzes the skill mismatch by using the framework of organizational learning processes from Crossan et al. (1999). The reasons for choosing the hotel industry is based on two reasons related to the characteristics of hotels in Indonesia. First, hotel employees as the only profession in Indonesia that supported by working standards recognized at the ASEAN level. Second, there is a tendency of high skill mismatches, supported from the supply side of labor with less hotel education compared to industrial demand and progressive hotel growth by Cedefop (2012), Poh et al. (2016), Santoso (2014), Suherlan and Permana (2016) and WEC (2017) confirmed that the hotel business is prone to experience skill mismatch.

\section{Literature review}

\subsection{Skill mismatch}

The International Labor Organization (ILO 2014) published a definition of skill mismatch as an encompassing type of imbalance between skills needed in the world of work. This definition becomes such an adhesive that unites various different terminologies and is used in prior researches. Exploring previous research would lead to finding terms such as over education and under education to refer to educational factors that trigger skill mismatch (Artes et al. 2014, Bender and Heywood 2011, Korpi and Tahlin 2009, Quintano et al. 2008). Previous researches also used a term called Jobs Mismatch (Sandulli et al. 2014), Overqualification (Brynin and Longhi 2006), while Cappelli (2015) categorized the skill mismatch along with gaps and skill shortages. These support the researches in organizational and management journals, where Smith (2012) mentioned that the gap as a skills gap. In other words, skill mismatch has several dimensions in the situations at work and appears in a variety of different terminologies across various fields of research.

Previous studies proved that skill mismatch at the micro and macro level would lead to negative effects. It would result in a less satisfactory salary level and was the cause of decreased levels of job satisfaction (Bender and Heywood 2011). Mahy et al. (2015) proved that skill mismatch could decrease productivity with a direct relationship between 
educational mismatch and company productivity. Further, in a macroeconomic space, Anuar Abraham (2015) mentioned that a lack of empirical data supporting the skill mismatch as a factor slowing the economic growth.

Skill mismatch is a workplace phenomenon caused by several factors. Leibert (2013) mentioned that skill mismatch was related to a lack of work experience and not a lack of education. Baker (2014) Research in the UK found that skill mismatch was triggered by prospective employees who were not properly prepared in an effort to find suitable jobs or lack of knowledge about how to get a suitable job. Both studies proved the existence of internal factors causing skill mismatch. On the other hand, the external causes of skill mismatch are explained by Hatos (2014) research which proved that there was a link between skill mismatch phenomena and the individual transition from education to the world of work. Skill mismatch in the workplace can be influenced by the speed of technological changes that have not been followed by new employee skills, differences in employee qualifications, lack of preparation of prospective employees, and the transition from education to the world of work.

\subsection{Organizational learning}

The literature discussing organizational learning cause arguments about the continuous process in organizations for learning so as to improve its capabilities appear. Saadat and Saadat (2016) stated that various disciplines examining organizational learning such as psychology, sociology, management, or economic industry increasingly enrich the body of knowledge from various perspectives. Previous researches results proved that organizational learning causes the organizations to gain knowledge, where learning becomes part of the methods, mechanisms, and processes of the organization into learning organizations (Mayo and Lank 1994). The keyword of the learning organization is the continuous process of improving itself by always learning. It can be found in the definition that supports organizational learning. Fiol and Lyles (1988) mentioned that organizational learning is a process of improving various actions through better knowledge and understanding.

Growing organizations are moving organizations. In transforming and striving for sustainability, the organization is an object learned in a learning organization. The definition is mentioned by Hodgets and Luthans (1994) who stated that organizational learning transforms by itself, anticipates things that make it extinct, finds new ways and is always about everything that must be learned.

Organizations applying the concept of organizational learning are the organizations that show certain characteristics and are built based on past learning and appropriate current learning. Adapted from Hitt (1995) and Skuncikiene et al. (2009) developed the characteristics of organizational learning as an organization that generally has organizational renewal abilities, with a style of management in the form of assistance and training. Personnel characteristics in organizational learning are shown by individuals who are always willing to learn and view mistakes as a part of the learning process. Team work in organizational learning is characterized by a cross-functional team, which allows for increased learning at all times in various departmental organizations. The analysis of the organizational learning characteristics found in the learning process as presented by Crossan et al. (1999) occurs at 3 levels namely individuals, groups and organizations. In these three levels, there is a multilevel learning process called the intuiting and interpreting at the individual level, integrating at the group level, and instituting at the organizational level. These three

Table 1. Organizational Learning dan Determination Process (source: adapted from Crossan et al. 1999)

\begin{tabular}{|c|c|c|c|}
\hline Level & Process & Input/Outcomes & Determination \\
\hline \multirow{6}{*}{ Individual } & \multirow{3}{*}{ Intuiting } & Experiences & \multirow{3}{*}{$\begin{array}{l}\text { Intuition is expressed in the form of subconscious willingness to learn } \\
\text { which comes with the recruitment and admission selection process as } \\
\text { a member of the community. } \\
\text { Adapting a new atmosphere as a member of the community. }\end{array}$} \\
\hline & & Images & \\
\hline & & Metaphors & \\
\hline & \multirow{3}{*}{ Interpreting } & Language & \multirow{3}{*}{$\begin{array}{l}\text { Learning resources in the organizations that come from tangible mate- } \\
\text { rial and tangible communication. } \\
\text { Understanding the work procedures. }\end{array}$} \\
\hline & & Cognitive Map & \\
\hline & & Conversation/dialogue & \\
\hline \multirow{3}{*}{ Group } & \multirow{3}{*}{ Integrating } & Shared Understandings & \multirow{3}{*}{$\begin{array}{l}\text { Expressed in the form of communication with individuals on the wor- } \\
\text { kplace to build and develop individuals in understanding something } \\
\text { so that it can change their understanding and behavior. } \\
\text { Mentoring from seniors to juniors and between individuals in the } \\
\text { community. }\end{array}$} \\
\hline & & Mutual adjustment & \\
\hline & & Interactive Systems & \\
\hline \multirow{3}{*}{ Organization } & \multirow{3}{*}{ Institutionalizing } & Routines & \multirow{3}{*}{$\begin{array}{l}\text { Organizations benefit from the learning process and become a joint } \\
\text { consensus. } \\
\text { Building a learning tradition in the organizations in the form of conti- } \\
\text { nuous learning, learning recognition and development. }\end{array}$} \\
\hline & & Diagnostic Systems & \\
\hline & & Rules and Procedures & \\
\hline
\end{tabular}


levels of learning are achieved through four stages in the framework of organizational learning which are referred to as $4 \mathrm{i}$ in learning. Continuing the work of Crossan et al. (1999), the following in the table 1 are the determinants of each learning process in the organization.

The learning process in organizational learning referred to as $4 \mathrm{i}$ which can be explained as follows: Intuiting is the beginning of a learning process where the process occurs subconsciously and can be shared with other individuals in the form of metaphor. The characteristics of intuition at the individual level can be understood even though it is difficult to explain. Nonaka and Takeuchi (1995) stated that this intuition is something that appears before individual actions and is difficult to share with other individuals. At the individual level, there is also an interpreting process whereas interpreting is the explaining, through words and or actions of insight or ideas to one's self and to others, the process from preverbal to verbal that produces developments in communication. At the next level, which occurs at the group level, it is called integrating which explains that the focus of integrating is coherent, collective action that can be achieved by communication and mutual understanding between individuals in the organization. The individual and group learning outcomes that occur in the body of the organization ultimately result in a consensus among members of the organization. Thus, the description of the learning process in organizations integrated is created from individuals, groups, and organizations.

\subsection{The link between skill mismatch and organizational learning}

Skill mismatch as a phenomenon in the workplace has attracted researchers' interest, because of its negative impact on productivity and job satisfaction. There have been few skill mismatch studies reviewed from an organizational or human resource management perspective. Therefore, previous researchers such as Cedefop (2012), ILO (2014) and Sala (2011) emphasized the need for research that uses companies as the objects so as to enrich the literature on skill mismatch. Most of the researches on skill mismatch were done in a macro or labor economics perspective and education perspective. However, from the period of 2004 to 2016, there were at least thirteen contributing literature from the company's perspective in response to skill mismatch. In general, the company mentions that the stressful situations due to changes in the business environment and the speed of technological change have an impact on changes in the difficulty level in recruiting employees who have the skills that suit their needs. Although it is known that training and retraining is one way to increase the skill level that employees have, not all companies can do this because they object to the value of the investment issued (Cedefop 2012). In other words, various literature from previous studies only examined the company's point of view in overcoming skill mismatch.

Kupets (2015) mentioned that the contribution of skill mismatch to happen in companies is that companies do not adapt to technological developments, do not provide training to employees, do not cooperate with educational institutions, employees who make mistakes in career decisions and do not adapt to the development of demand skills and technology and also ongoing training. Further, he mentioned that companies also do not provide relevant labor market information, do not provide adult training and other support to workers and do not encourage job creation and internship application. Dealing with skill mismatch in the organization was written by Susaeta et al. (2014) and found that the flow of dealing with skill mismatch could be done by Motivation, Training, Encouraging, Identifying Talents, Attracting talent and developing talent. $80 \%$ of respondents said that academic training was not enough to meet the company's work requirements, so offering training in the workplace was one of the company's efforts to get talent for both now and in the future.

Previous literature on dealing with mismatch skills mention that there is the existence of job training, apprenticeship and developing talent, where these variables are the characteristics of actions in organizational learning. In the study of an organization, previous researchers had proven that the implementation of organizational learning brings organization to survive in the midst of a crisis with the capabilities it possesses (Fiol and Lyles 1988, Mayo and Lank 1994, Saadat and Saadat 2016, Skuncikiene et al. 2009). Thus it can be expected that the negative effects of skill mismatch can be reduced by the implementation of organizational learning.

\section{Research method}

This research used a qualitative-descriptive approach, so this research would try to understand how the skill mismatch experience was in the workplace directly from the parties who experienced it. Several reasons for using a qualitative design are as follows: (1) skill mismatch was a new phenomenon in the realm of organizational research that required a special understanding in order to obtain accurate information from various actors involved in implementing it at the company level, (2) only with a qualitative approach, this research would get the information about the process of how skill mismatch occurred in the company and how to overcome it.

Kirk and Miller (1986) mentioned that qualitative research is a tradition in social science which is fundamentally dependent on the researchers' observations and it relates to the people involved. This is supported by Bradshaw et al. (2017) explanation which stated that the qualitative descriptive research design is relevant for obtaining information 
directly from parties who experience a particular phenomenon.

The data in this study were obtained by in-depth interviews with key informants at four Human Resources Managers in five-star hotels in Indonesia, such as Medan, Jakarta, Semarang, and Denpasar in the period of MayAugust 2018. The four cities chosen represented big cities in Indonesia as an archipelagic country. The distance between the cities is between 500 and 1900 kilometers. The hotels were chosen based on five-star classification and that they were the market leader in the city. The subjects of this research were the best business units in each city to become samples for managing mismatch skills in high-performance organizations. Before the face-to-face interview meetings, the researcher previously called and send the informants an official letter explained the purpose of interview which was for research deliberately. The data collection procedure was done by establishing an interview protocol, selecting informants and research locations, conveying the interview objectives to the informants, and conducting interviews with a list of open-ended questions (Creswell 2014). The interview protocol was developed from a literature review synthesis on human resource management practices, skill mismatch, and organizational learning.

The interview results were written in an interview transcript according to the situation in the recording. The interview theme consisted of the practice of human resource management in the hotel business, recruitment, selection, and problems encountered between the recruitment and selection, matching worker supply skills. The questions proposed to the key informants were based on research problems and were sent by e-mail before the interview was carried out to make the informants understand about the direction of the interview and to make them prepared with the actual data. In conducting interviews, additional questions emerged that were initially not in the list of written questions but were previously submitted by the researcher to enrich the discourse and discussion on the management of the mismatch skills in the workplace conveyed by the informants.
The list of written questions submitted is as follows: how the recruitment process at the company is, what the company's procedure is if it does not get employee candidates according to job qualifications, how the company attempts to add employee skills, who involved in efforts to add employee skills and how interactions between parties is, how the difficulties posed by employees with skill mismatch, how long it will take to add employee skills, how the company spent the budget to take action to add employee skills, whether the actions of human resource managers add employee skills affect the company's strategy in gaining profits and long-term goals. Additional questions submitted by the researcher at the time of the interview according to the informant's answers could be summarized as follows: why choosing candidates with skill mismatch, what factors supporting employees immediately getting matching skills are, whether the difficult situation of getting matching skills for employees is also experienced by hotel managers others, how the hospitality HR Manager professional association responded to the situation is. The results of the interviews were analyzed using Qualitative Data Analysis Miner Lite software V2.05 to set the code, theme and frequency distribution of the interview results. Classification and code making for the interview results that had been conducted were in accordance with the research framework which focuses on the skill mismatch and human resource management practices, namely training, mentoring and development. The next code classification was at the level of organizational learners in overcoming the skill mismatch which is intuiting, interpreting, integrating and institutionalizing.

\section{Result and discussion}

The 4 hotels chosen as the object of this study represented 4 major cities in Indonesia, namely Santika Premiere Medan, Aston Rasuna Jakarta, Grand Candi Semarang, and Sovereign Denpasar. In-depth interviews were conducted in each hotel with the Human Resources Manager as the key informant. Each hotel was a hotel that had a competitive

Table 2. The skill mismatch in hospitality business (source: Primary Data)

\begin{tabular}{|l|c|l|l|c|c|}
\hline Hotel & Code & \multicolumn{1}{|c|}{ Causes of Skill Mismatch } & $\begin{array}{l}\text { Step to Minimize the Skill } \\
\text { Mismatch Effects }\end{array}$ & $\begin{array}{c}\text { The salary for new emplo- } \\
\text { yees with skill mismatch }\end{array}$ & $\begin{array}{c}\text { Additional salary } \\
\text { for mentors }\end{array}$ \\
\hline Medan & A & $\begin{array}{l}\text { Limited candidates with appropria- } \\
\text { te educational backgrounds }\end{array}$ & $\begin{array}{l}\text { Training, Mentoring, } \\
\text { Development }\end{array}$ & Yes & No \\
\hline Jakarta & B & $\begin{array}{l}\text { Lack of labor supply in the hospita- } \\
\text { lity sector }\end{array}$ & $\begin{array}{l}\text { Training, Mentoring, } \\
\text { Development }\end{array}$ & Yes \\
\hline Semarang & C & $\begin{array}{l}\text { Limited candidates, lack of supply } \\
\text { of hospitality workers } \\
\text { Schools do not provide the edu- } \\
\text { cation needed by the hotel }\end{array}$ & $\begin{array}{l}\text { Training, Mentoring, } \\
\text { Development }\end{array}$ & No \\
\hline Denpasar & D & $\begin{array}{l}\text { Hospitality education background } \\
\text { does not guarantee matching skills }\end{array}$ & $\begin{array}{l}\text { Training, Mentoring, } \\
\text { Development }\end{array}$ & No & No \\
\hline
\end{tabular}


advantage in each city. All hotels had the characteristics as hotels that relied on the sales of meetings, incentives, conferencing, and exhibitions as a part of their superior products. The interview results on how skill mismatches occurred in businesses they managed are presented in the following table:

Table 2 illustrates the causes of employee skill mismatch in each hotel. Skill Mismatch is a situation where the company employs employees without skills according to job demands. Each hotel provided an equivalent answer that employees with skill mismatch were recruited because of limited candidates. The number of skills mismatch recruitment ranged from $15 \%-30 \%$ in each hotel. Hotels in Medan and Denpasar said that the number of skill mismatch employees working in the company reached $30 \%$. Hotels in Semarang said that there were $10-15 \%$ of skill mismatch employees.

Each hotel relied on training and mentoring to minimize the impact of skill mismatch. Rewards were given after the employee was able to achieve skill matching conditions, in the form of career development. There were differences in the treatment of each hotel in terms of compensation for skill mismatch employees. 2 hotels compensated skill mismatch employees who were in training and mentoring, while 2 other hotels did not compensate. The reason for not giving compensation from the hotels in Jakarta and Denpasar to skill mismatch employees was because the hotel had provided free education. This was in contrast to two other hotels that stated that even though they had a trial status or in a training, skill mismatch employees still received compensation as probation employees.

There were similarities in the attitude of all hotels where the seniors tried to be the mentors for their juniors. Every mentor or trainer in the hotel company did not get additional compensation for his efforts to provide training and mentoring. The four hotels provided firm answers regarding the absence of additional compensation for mentors:

Hotel A conveyed that their decision to train skill mismatch employees gave benefits to the company, and there was no additional compensation for the mentors. The following is what was stated by the Human Resources Manager of Hotel A:

Nothing. It is a part of work. The company does not lose by allocating a budget for their training. When we train them, they have become our employees...So, why do we want to train them for 3 months, it is because we really need that position.

Hotel B mentioned that the mentor's duty to train skill mismatch employees was such a challenge in his career. The following is what was stated by the Human Resources Manager of Hotel B: the supervisor should transfer his knowledge to the juniors, so there are no more mistakes. We give no incentives... because discussing learning itself means that we talk about the career. If you want to work more, then a career is the prize. The challenge is the career itself.

Hotel $\mathrm{C}$ mentioned that the training and mentoring process was a company regulation and it provided religious motivation for senior employees to have the willingness to become mentors. The following is what was stated by the Human Resources Manager of Hotel C:

I emphasize to employees to be generous in terms of knowledge. This is the regulation that I emphasize to each section head that we must open ourselves to someone who wants to learn. And even the head department himself is permitted to share for the sake of every employees' aspiration who wants to develop himself and to develop any vacant positions. We give them knowledge we know, and we do not rule out the possibility of people who want to go forward. Even, the graduates from this hotel are considered interesting for other hotels... This place is like a school.

Hotel $\mathrm{D}$ stated that training and mentoring activities for skill mismatch employees were the responsibility of senior employees with matching skills, so there was no additional compensation. The following is what was stated by the Human Resources Manager of Hotel D:

There is no compensation because that is part of his duty to train. If there are employees who still cannot work well, we will see how the department head train them, whether he is lacking of supervision or just careless.

Similarities in the informants' answers regarding the absence of financial rewards for mentors was a sign of how organizations played a big role in instilling the learning culture as an organizational value. Explaining how mentors had the willingness to do additional tasks without financial reward supporting research (Ehrich and Hansford 1999) which mentions various variations in mentoring and relationships between junior and senior employees and organizations to determine the best performance achievement in their business.

The informants of this research provided the fact that skill mismatches were overcome by the practice of learning organizations and the cause of mismatch skills was a lack of supply of hospitality in the hospitality sector. The Human Resources Manager's efforts to make regular regulations allowing the mismatch employees to acquire the skills needed to work by providing training and mentoring.

The willingness of senior employees to train their juniors to get matching skills supported Nonaka and Takeuchi (1995) argument mentioning about the shared experience so that the creation of common perspectives was carried 
out by organizations to create organizational knowledge creation. Continuous knowledge creation could be understood as the organization's effort to respond to changes in a dynamic business environment so as to win the competition. In understanding the skills addition expected by the company, knowledge could not be seen as a single tool but it was a formulation of the workability for employees. The organizational efforts to respond to skill mismatch through training clarified the research results (Cedefop 2012) stating that the role of training and career development could reduce skill mismatches in the workplace. However, the organization's efforts to provide training facilities and the willingness to develop employee careers also determined changes in the negative effects of mismatch skills. The role of the mentor, namely the seniors in the organization to add skills to their junior determined the success of the skills transfers to change the mismatched to the matched ones. Professional relations to transfer skills from skilled employees to unskilled employees were mentoring activities as stated by (Ehrich and Hansford 1999) that the main role of mentoring was learning new skills and becoming competent.

It was in accordance with the answers from the informants that could be classified in the incidence of recognized skill mismatches, organizational activities to overcome them through training, mentoring and career development. The results of the interviews analyzed using Qualitative Data Analysis Miner Lite showed a frequency distribution of the number of words in the category of incidents of skill mismatch, training, mentoring, and development as shown below

In the Figure 1 frequency distribution of skill mismatch and how to overcome above, it can be seen that the skill mismatch incident is delivered by the key informant as one of the regular events of the organization. The efforts to increase employee skills were carried out by conducting training and development which ranks as the top 2 and 3 after the mismatch skill. The diagram is a representation of the answers from the key informants who said that the training

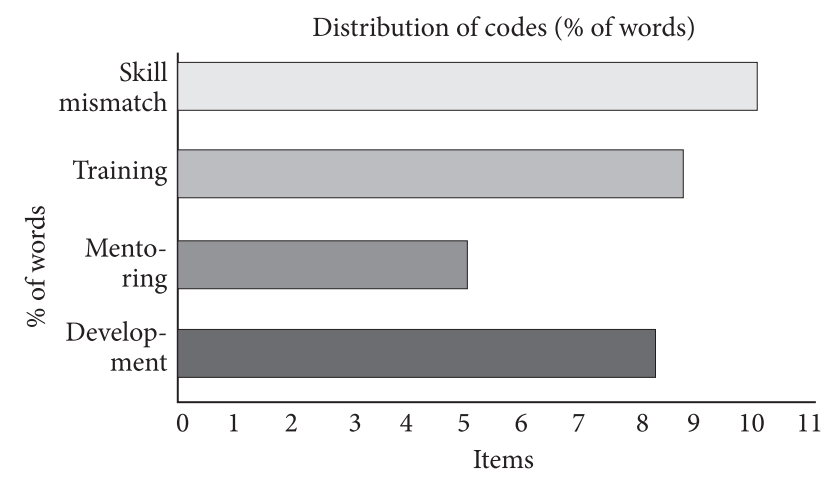

Figure 1. Frequency distribution of skill mismatch and how to overcome (source: QDA Minerlite) was done by skill mismatch employees independently, while mentoring was the involvement of more senior employees with the position of supervisor or manager. Development category is shown to be in the third rank because employee career development was such a reward for employees who were able to add their skills so that they got skill matching.

\subsection{4i as a skill mismatch framework analysis}

Based on the informants' answers about the organizational strategies to overcome skill mismatch, several keywords were found that led to various roles in the learning process to add skills. The role of individuals and organizations delivered by the senior employees with the mentoring process had the characteristics of learning organizations mentioned in previous researches. It could be concluded that the relations between the actors in the learning organization to overcome the mismatch skill was according to the framework 4i compiled by Crossan et al. (1999) which mentioned about the learning process through intuition, interpreting, integration, and institutionalizing. The answers from the key informants who were the HR managers in the best hotels in 4 major cities in Indonesia had been categorized by using the $4 \mathrm{i}$ determinants. The intuiting determinant was manifested in adopting a new atmosphere as a member of the community, interpretation by understanding work procedures, integrating by mentoring from seniors to juniors and between individuals in the community, and finally institutionalizing which was categorized as an activity to build a learning tradition in the organizations in the form of continuous learning, learning recognition and development.

The $4 \mathrm{i}$ framework was used to analyze the changing process from skill mismatch to match skill, from interview transcript data with code classifications according to the $4 \mathrm{i}$ determinants, the analysis process using Qualitative Data Analysis Miner Lite generates diagrams can be described as follows in Figure 2.

The Figure 2 frequency distribution of learning process above is the frequency of keywords distribution that was

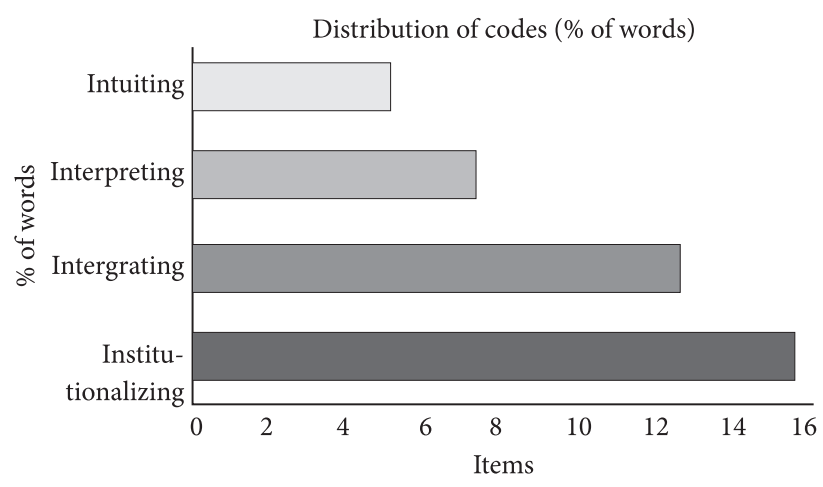

Figure 2. Frequency distribution of learning process (source: QDA Minerlite) 
classified according to the $4 \mathrm{i}$ determinants in the organizational learning based on the results of interviews with the key informants. The intuitive characteristics of the learning process that occurred in the workplace were found through the willingness to accept the job even without adequate skills. As what had been stated by Crossan et al. (1999) that intuiting is a process done under subconsciousness. Interpreting in the learning process of skill mismatch employees was found through an understanding of work procedures. Integrating was found in the process of training and mentoring. At the organizational level, the learning process was seen in the form of regulation and became a habit at work. It was found in the form of organizational support to provide career development for employees who were able to overcome skill mismatch.

The frequency distribution of the learning process in the company to overcome the skill mismatch indicated that the organizational level was more dominant than the group and individual levels. The second is the interpreting process occurred at the group level. It is then followed by intuiting and interpreting at the individual level. In this case, it could be concluded that the company played a big role in overcoming skill mismatch. The decision of the Human Resources Managers to recruit skills mismatch employees was realized as an inevitable action so that treatment must be done to overcome them. The company's dominance to deal with employees with skill mismatches was shown by the company by making regulations so that the process of sharing skills from matching employee skills to skills mismatch employee occurred.

The lack of employee candidates with matching skills generated from educational institutions made the company in an inevitable situation to recruit skill mismatch employees. Thus, it could be concluded that skill mismatch also occurred due to external factors, where the number of hospitality education institutions did not go according to the increasing number of hospitality businesses that continued to grow. Therefore, the causes of skill mismatch can be described in the Figure 3.

Based on the information from the key informants, the causes of skill mismatch in the workplace were the lack of candidates and educational outcomes that were not in accordance with the needs, resulting in the company to recruit inappropriate skills and was such an inevitable step. The causes of skill mismatch in hotel organizations in Indonesia could be distinguished as external and internal incentives. The external factors were related to the availability of education and training institutions as candidate providers. The internal factors were related to recruitment decisions that did not have a choice that matched the skills needed. For the hotel employees at a certain level, such as those who worked at the front row, the requirements were simpler. The qualifications and provision of employee skills were not categorized into a requirement and was replaced by a requirement of physical appearance and foreign language skills.

The organization was responsible for the decision to recruit employees with skill mismatch in the form of providing training by mentoring. Figure 3 illustrates that there were external and internal incentives that supported the occurrence of skill mismatch at the individual level. At the organizational level, the institutionalizing process took place strongly and produced the highest tendency compared to the process of intuiting, interpreting and integrating that encouraged the learning process from senior employees to junior employees. The senior employees' willingness to mentor in the training did not merely come from the willingness between individuals involved, but it was fully supported by the role of the organization. This was evidenced by the information of all key informants who did not receive additional fees when providing training and mentoring. This finding adds an understanding of mentoring as mentioned by (Ehrich and Hansford 1999) that mentors naturally get financial rewards. The evidence found in the field about the absence of financial rewards for mentors who contributed to improving the situation of skill mismatch was an illustration of the organizational involvement in sharpening learning programs into their culture.

Figure 3 describes the skill mismatch that occurred due to external impulses and internal factors. When skill mismatch occurred at the individual level, there was a big intervention from the organization that added skills to skill mismatch employees. The organizational intervention was given in the form of regulations that bind the seniors and juniors so that learning processes and skills were successfully added. The process of institutionalizing at the organizational level could occur in reverse where it was not preceded by the process of integrating and interpreting at the level

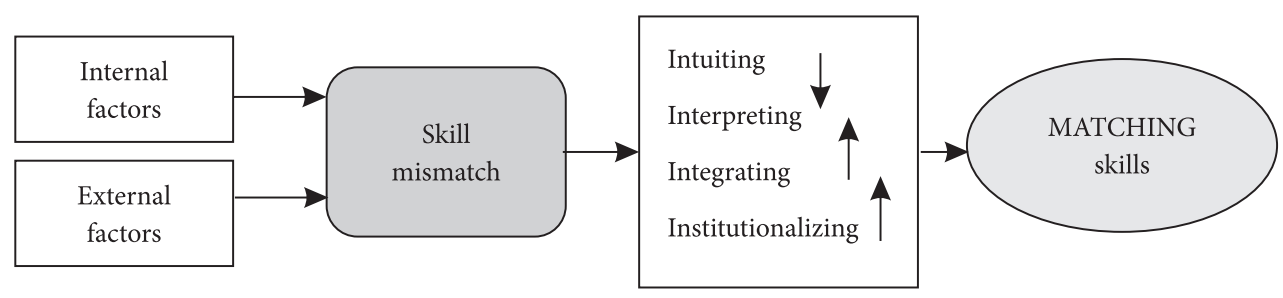

Figure 3. Model of organizational learning on skill mismatch (source: Primary Data) 
of individuals and groups. Institutionalizing that occurred came from the organization as a strategy to overcome the skill mismatch effects and it was followed by the process of integrating and interpreting when the junior and senior employees were involved in the process of adding skills in training and mentoring. In the learning process, there was a skill mismatch employee involvement at an intuitive level, whereas their intuition was driven subconsciously and happened since they received the commitment to work without the appropriate skills. The result of the process of organizational learning that took place in reverse in the company produced employees with matching skills. This finding supported the research on previous learning organizations. The $4 \mathrm{i}$ framework that explains the learning process in organizations Crossan et al. (1999) is supported by Castande and Rios (2007) showing that the learning process could take place in two directions, from the individuals to organizations, and vice versa where the organizational role influenced the individuals to learn. Maintaining a willingness to learn was one of the organization's efforts to reduce their weaknesses in terms of providing employee matching skills.

\section{Conclusions}

Skill mismatches occurred in hotel companies in Indonesia because of the lack of suitable candidates. The growth of the hospitality business had not received support in the form of providing prospective employees who were ready to work from related education and training institutions. To overcome the skill mismatch, hospitality companies created a set of rules related to training and mentoring so that additional skills were successfully added. The learning process in the organization with skill mismatch employees took place continuously and involved all employees and also the organization played an important role in controlling the process. The process of changing mismatch skills into skill matching in hospitality companies in Indonesia took place at the individual level through interpreted and integrated intuition which brought benefits to the organization. The opposite also happened where the willingness to learn to minimize the negative effects of skill mismatch starts from the role of the organization that instilled a culture of learning for all of their employees so as to generate a high willingness even without any financial reward.

The practical implication of this study is to convey these findings to policy makers so that they will pay more attention to the provision of prospective employees for the hospitality business that is growing progressively. The labor supply in the hospitality sector must be added and should be completed with curriculum support that suits the needs of the companies. A false perspective on the company that it should provide continuous training and mentoring whenever there is a recruitment of new employees needs to be improved. The function of education and training to provide skills for prospective employees did not exist in business organizations. The function of the training carried out by the company was such a burden and could reduce its agility in facing business competition. Policymakers need to design educational and training institutions to provide prospective employees with skills that suit the needs of the organization so that the practice of skill mismatch can be avoided. Public education is the second thing that policy makers need to do so that people realize that getting a job which is not in accordance with their education and skills will contribute to long-term negative impacts. Policies that encourage people to work in accordance with the portfolios will reduce the incidence of mismatch skills.

Overall, the individual productivity will experience a decrease with an additional work to train and mentor. Organizations need to think about the financial rewards for mentors who contribute to adding skills to employees with mismatch skills. The theoretical implications of this article are on the research foundations about the skill mismatch at the level of companies that use the tradition of learning organizations. The theoretical implications of this study are put on the research foundation regarding the learning process in organizational learning that does not work sequentially. The inverse process of organizational learning is a finding that provides a new perspective on the learning process in a company.

The limitations of this study is in the use of one organizational learning framework only to analyze the management of mismatch skills in the workplace. Future researches may consider other dimensions of skills, such as knowledge and work attitudes to analyze skill mismatches, so as to get competent employees. Future researches can be done by using different research methods and to calculate the productivity of employees who provide training and mentoring during their working hours so that the effect of mismatch skills is not only on the skill mismatch employees but also on matching employees because they have to take more times to add skills to their colleagues. This research is part of a dissertation on skill mismatch in the hospitality business in Indonesia. The authors are grateful to the Ministry of Research and Higher Education of the Republic of Indonesia under 2018 Dissertation Research Grant.

\section{Acknowledgements}

The authors are thankful for the support from The Ministry of Research and Higher Education of the Republic of Indonesia under 2018 Dissertation Research Grant.

\section{References}

Abraham KG (2015) Is skill mismatch impeding U.S. economic recovery? ILR Review 68 (March): 1-24. https://doi. org/10.1177/0019793914564962 
Allen J, Vries R De (2004) Determinants of skill mismatches: the role of learning environment, the match between education and job and working experience. Maastricht: Royal Academy of Sciences Amsterdam, 45-63 https://www.econbiz.de/Record/determinants-of-skill-mismatches-the-role-of-learningenvironment-education-job-match-and-working-experienceallen-jim/10003527250

Anuar A, Mansor W, Din B (2016) Skills mismatch in small-sized enterprises in Malaysia. International Journal of Economics and Financial Issues 6 (7): 120-124 http: www.econjournals. com

Artes J, Salinas-Jimenez M, Salinas-Jimenez J (2014) Small fish in a big pond or big fish in a small pond? The effects of educational mismatch on subjective wellbeing. Social Indicators Research 119 (2): 771-789 https://link.springer.com/article/1 0.1007\%2Fs11205-013-0526-1

Baker K (2014) The skills mismatch. London: The Edge Foundation.

Bender KA, Heywood JS (2011) Educational mismatch and the careers of scientists. Education Economics 19 (3): 253-274. https://doi.org/10.1080/09645292.2011.577555

Bradshaw C, Atkinson S, Doody O (2017) Employing a qualitative description approach in health care research. Global Qualitative Nursing Research 4 (1-8). https://doi. org/10.1177/2333393617742282

Brynin M, Longhi S (2006) Overqualification: major or minor mismatch? Economics of Education Review 28. Essex. https:// doi.org/10.1016/j.econedurev.2008.01.003

Castande ID, Rios MF (2007) From individual learning to organizational learning. The Electronic Journal of Knowledge Management 5 (4): 363-372.

Cappelli PH (2015) Mismatches: evidence and arguments for the. ILR Review 68 (March): 251-290. https://doi. org/10.1177/0019793914564961

Cedefop (2012) Skill mismatch. The role of the enterprise. Research Paper No. 21 European Centre for The Development of Vocational Training. Luxembourg: Publications Office of the European Union 2012.

Chiswick B, Miller P (2010) The effects of educational-occupational mismatch on immigrant earnings in Australia, with international comparisons. International Migration Review 44 (4): 869-898. https://doi.org/10.1111/j.1747-7379.2010.00829.x

Chowdhury SR (2014) Skill mismatches in Indian labor market: policy priorities \& challenges ahead. Indian Journal of Industrial Relations 49 (3): 422-438.

Creswell JW (2014) Research design, qualitative, quantitavive, and mixed methods approaches (4th ed). SAGE. Sage Publications, inc.

Crossan M, Lane H, White R (1999) An organizational learning framework: from intuition to institution. Academy of Management 24 (3): 522-537. https://doi.org/10.2307/259140

Dobbs R, Madgavkar A (2014) The world at work: matching skills and jobs in Asia. Prospects 44 (2): 197-210. https://doi. org/10.1007/s11125-014-9300-7

Ehrich LC \& Hansford B (1999) Mentoring: pros and cons for HRM. Asia Pacific Journal of Human Resources 37 (3): 92 107. https://doi.org/10.1177/103841119903700307
Fiol C, Lyles M (1988) Organizational learning. University of Illinois Urbana-Champaign (Vol. 7). Illinois: Bureau of Economic and Business Research University of Illinois.

Guvenen F, Kuruscu B, Tanaka S, Wiczer D (2015) Multidimensional skill mismatch (NBER Working Paper No. 21376). Cambridge, MA 02138 http://www.nber.org/papers/w21376

Hatos R (2014) Skills mismatch of the young people at the European level. Annals of Faculty of Economics, University of Oradea, Faculty of Economics 1 (1): 431-439 https://ideas. repec.org/a/ora/journl/v1y2015i1p431-439.htm

Hitt W (1995) The learning organization: some reflections on organizational renewal. Leadership and Organization Development Journal 16 (8): 17-25. https://doi.org/10.1108/ 01437739510097996

Hodgets R \& Luthans F (1994) International management: culture, strategy, and behavior. Irwin/McGraw-Hill, 2000 https:// books.google.co.id/books?id=I1gCFLZ6nRwC

ILO (2014) Skills mismatch in Europe: Statistics Brief: International Labour Office, Department of Statistics. Geneva: ILO, 2014 http://www.ilo.org/wcmsp5/groups/public/---dgreports/--stat/documents/publication/wcms_315623.pdf

Kirk J, Miller M (1986) Reliability and validity in qualitative research. Kirk J (Ed) (1st ed). California: SAGE. Sage Publications, inc. https://doi.org/10.4135/9781412985659

Korpi T, Tahlin M (2009) Educational mismatch, wages, and wage growth: Overeducation in Sweden, 1974-2000. Labour Economics 16 (2): 183-193. https://doi.org/10.1016/j. labeco.2008.08.004

Kupets O (2015) Skill mismatch and overeducation in transition economies. IZA World of Labor. Germany. https://doi. org/10.15185/izawol.224

Kurniawan S (2016, March). Hotel Tumbuh, Namun Sulit Mencari Pegawai. Ada Apa? http://marketeers.com/hotel-tumbuhnamun-sulit-mencari-pegawai-ada-apa/

Leibert A (2013) Are skilled workers scarce? Evidence from employer surveys in Minnesota. Minnesota https://mn.gov/ deed/assets/second-round-skills-gap_tcm1045-133680.pdf

Mahy B, Rycx F, Vermeylen G (2015) Educational mismatch and firm productivity: do skills, technology and uncertainty matter? Belgium: IZA research network.

Mayo A, Lank E (1994) The power of learning: a guide to gaining competitive advantage https://books.google.co.id/books/ about/The_Power_of_Learning.html?id=g3yEQgAACAAJ\& redir_esc $=y$

Messinis G, Olekalns N (2007) Skill mismatch and returns to training in Australia: some new evidence ${ }^{\star}$. Melbourne: Departement of Economics, The University of Melbourne.

Modestino A (2010) Mismatch in the labor market: measuring the supply of and demand for skilled labor in New England. New England Public Policy Center Research Report. Boston. https://doi.org/10.2139/ssrn.1947436

Nonaka I, Takeuchi H (1995) The knowledge-creating company: how Japanese creates the dynamic of innovation. Oxford University https://books.google.co.id/books/about/ The_Knowledge_creating_Company.html?id=B-qxrPaU1MC\&redir_esc $=y$ 
Park K (2013) English language and skill mismatch: the case of South Korea. African and Asian Studies 12 (4): 391-414. https://doi.org/10.1163/15692108-12341274

Pellizzari M, Fichen A (2013) A new measure of skills mismatch: theory and evidence from the survey of adult skills (PIAAC) (Working Papers No. 153 No. 153). https://doi. org/10.1787/5k3tpt04lcnt-en

Poh S, Yashaas R, Yean C (2016) Indonesia Hotel Watch 2016. Singapore.

Quintano C, Castellano R, D’Agostiono A (2008) Graduates in economics and educational mismatch: the case study. Journal of Education and Work 21 (3): 249-271 https://eric. ed.gov/?id=EJ801984

Saadat V, Saadat Z (2016) Organizational learning as a key role of organizational success. Procedia - Social and Behavioral Sciences 230: 219-225. https://doi.org/10.1016/j. sbspro.2016.09.028

Sala G (2011) Approaches to skills mismatch in the labour market: a literature review 1. Papers: Revista de Sociologia 96 (4): 1025-1045. https://doi.org/10.5565/rev/papers/v96n4.171

Sandulli F, Baker P, Lopez-Sanchez J (2014) Jobs mismatch and productivity impact of information technology. Service Industry Journal 34 (13): 1060-1074 https://www.tandfonline.com/doi/fu 11/10.1080/02642069.2014.939638?scroll=top\&needAccess=true

Santos MS (2012) Education, educational mismatch, and wage inequality evidence for different European countries. Universidade Da Beira Interior https://ubibliorum.ubi.pt/bitstream/10400.6/2950/1/Tese \%28versão final\%29.pdf

Santoso (2014) Analisis Pertumbuhan Jumlah Kamar Hotel, Jumlah Wisatawan dan Mahasiswa Perguruan Tinggi
Pariwisata Program Studi Perhotelan. Jurnal Media Wisata 12 (1): 43-69.

Senge P (1990) The fifth discipline: the art and practice of the learning organization. Currency Doubleday.

Skuncikiene S, Balvociute R, Balciunas S (2009) Exploring characteristics of a learning organization as learning environment. Social Research 1 (1): 64-75 http://www.su.lt/bylos/mokslo_ leidiniai/soc_tyrimai/2009_15/skuncikiene.pdf

Smith D (2012) How employers can help solve the skills gap. Harvard Business Review, 1-5 https://hbr.org/2012/02/howemployers-can-help-solve- $t$

Suherlan H, Permana J (2016) Dalam meningkatkan keunggulan bersaing berkelanjutan melalui aliansi strategis. Jurnal Administrasi Pendidikan 13 (1): 107-113 https://media.neliti. com/media/publications/72497-ID-dalam-meningkatkankeunggulan-bersaing-b.pdf

Susaeta L, Apascaritei P, Pin Arboledas J (2014) Manager's perception of skills mismatch in Spanish companies. WP-1080-E (Vol. 3). Madrid. https://doi.org/10.2139/ssrn.2537626

Wang Y, Ellinger AD (2008) Organizational learning and innovation performance: a review of the literature and the development of a conceptual framework and research hypotheses. Academy of Human Resource Development International Research Conference in the Americas. Illinois: ERIC http:// eric.ed.gov/?id=ED501671

WEC (2017) Travel and tourism competitiveness report 2017/Asia pacific results http://reports.weforum.org/travel-and-tourismcompetitiveness-report-2017/asia-pacific-results/?doing_wp_ cron $=1540614152.4146440029144287109375$ 